\title{
Assessment of the ecological quality of the Minho estuary (Northwest Iberian Peninsula) based on metal concentrations in sediments and in Corbicula fluminea
}

\author{
Pedro A. Reis ${ }^{1, *}$, Lúcia Guilhermino ${ }^{1,2}$, Carlos Antunes ${ }^{1,3,5}$ and Ronaldo Sousa ${ }^{1,4}$ \\ ${ }^{1}$ CIMAR-LA/CIIMAR-Centro Interdisciplinar de Investigação Marinha e Ambiental, Universidade do Porto, \\ Porto, Portugal. \\ ${ }^{2}$ ICBAS-Instituto de Ciências Biomédicas de Abel Salazar, Universidade do Porto, Departamento de Estudos de \\ Populações, Laboratório de Ecotoxicologia, Porto, Portugal. \\ 3 Aquamuseu do rio Minho, Vila Nova de Cerveira, Portugal. \\ ${ }^{4}$ CBMA - Centre of Molecular and Environmental Biology, Department of Biology, University of Minho, Braga, \\ Portugal. \\ ${ }^{5}$ Escola Superior Gallaecia-Vila Nova de Cerveira, Portugal. \\ * Corresponding author: pedroareis@ ciimar.up.pt
}

Received: 25/09/2013 Accepted: 21/03/2014

\begin{abstract}
Assessment of the ecological quality of the Minho estuary (Northwest Iberian Peninsula) based on metal concentrations in sediments and in Corbicula fluminea

The concentrations of metals $(\mathrm{Cd}, \mathrm{Cr}, \mathrm{Cu}, \mathrm{Fe}, \mathrm{Ni}, \mathrm{Pb}$ and $\mathrm{Zn})$ in sediments and the soft tissues of Corbicula fluminea from the Minho estuary (Northwest Iberian Peninsula) were determined to assess the spatial variation of metal bioavailability and to classify the ecological quality of the estuary. Metal concentrations in sediments showed significant spatial variation $(p<0.0003)$ and ranged in concentration (dry weight basis) from 0.025-0.36 mg Cd/kg, 7-16 mg Cr/kg, 2.7-24.6 mg Cu/kg, 7.3-45 mg Ni/kg, 4.1-15 mg Pb/kg and 37.3-110 mg Zn/kg. According to the Norwegian Pollution Control Authority metal concentration guidelines for sediments, this first ecological quality classification of the Minho estuary is "Class I/II-Background/Good." Metal concentrations in the soft tissues of $C$. fluminea also showed significant spatial variation $(p<0.0001)$ and ranged in concentration (dry weight basis) from 1.1-2.5 mg Cd/kg, 1.0-1.8 mg Cr/kg, 34-71 mg Cu/kg, $5.8-11 \mathrm{mg} \mathrm{Ni} / \mathrm{kg}, 0.45-1.3 \mathrm{mg} \mathrm{Pb} / \mathrm{kg}$ and $136-161 \mathrm{mg} \mathrm{Zn} / \mathrm{kg}$. The high $\mathrm{Cu}$ concentrations bioaccumulated by $C$. fluminea in the Minho estuary suggest that the estuary should be classified as "Class II/III-Moderately/Remarkably Polluted." Thus, the primary contributions of this work are that $C$. fluminea proved to be a good and adequate biomonitor of metal contamination in the Minho estuary and that it could be used to assess the ecological quality of estuarine ecosystems worldwide.
\end{abstract}

Key words: Minho, sediments, soft tissues, spatial variations, Corbicula fluminea.

\section{RESUMEN}

Evaluación de la calidad ecológica del estuario del Miño (Peninsula Iberica Noroeste) basada en la concentración de metales en sedimentos y en Corbicula fluminea

La concentración de metales ( $\mathrm{Cd}, \mathrm{Cr}, \mathrm{Cu}, \mathrm{Fe}, \mathrm{Ni}, \mathrm{Pb}$ and $\mathrm{Zn}$ ) en sedimentos y tejidos blandos de Corbicula fluminea procedentes del estuario del Minho (Noroeste Península Ibérica) fue determinada para evaluar variaciones espaciales en la biodisponibilidad de los metales y para comparar diferentes clasificaciones ecológicas de calidad. Los sedimentos retuvieron metales en rangos (peso seco) entre 0.025-0.36 mg Cd/kg, 7-16 mg Cr/ $\mathrm{kg}, 2.7-24.6 \mathrm{mg} \mathrm{Cu} / \mathrm{kg}, 7.3-45 \mathrm{mg} \mathrm{Ni} / \mathrm{kg}$, 4.1-15 mg Pb/kg y 37.3-110 mg Zn/kg, lo que revela una variación espacial significativa ( $\mathrm{p}<0.0003$ ). Las directrices sobre concentración de metales en sedimentos recomendadas por la Norwegian Pollution Control Authority permitieron obtener una primera clasificación de calidad ecológica del estuario del Miño designada como "Clase I/II-Basal/Buena”. En los tejidos blandos de C. fluminea también se encontraron variaciones espaciales significativas, ( $\mathrm{p}<0.0001)$ y sus concentraciones variaron (peso seco) entre 1.1-2.5 mg Cd/kg, $1.0-1.8 \mathrm{mg} \mathrm{Cr} / \mathrm{kg} ; 34-71 \mathrm{mg} \mathrm{Cu} / \mathrm{kg}, 5.8-11 \mathrm{mg} \mathrm{Ni/kg,} \mathrm{0.45-1.3} \mathrm{mg} \mathrm{Pb/kg} \mathrm{y} 136$ $161 \mathrm{mg} \mathrm{Zn/kg}$. Sin embargo, teniendo en cuenta las altas concentraciones de Cu bioacumuladas por $\mathrm{C}$. fluminea el estuario del 
Miño debería estar clasificado como "Clase II/III-Moderadamente/Notablemente contaminado”. Así, la principal conclusión de este trabajo, es que C. fluminea ha demostrado ser un adecuado indicador de la contaminación en el estuario del Miño y podría ser utilizada para evaluar la calidad ecológica de los ecosistemas estuarinos a nivel mundial.

Palabras clave: Miño, sedimentos, tejidos blandos, variación espacial, Corbicula fluminea.

\section{INTRODUCTION}

Anthropogenic contaminants are continually discharged into aquatic ecosystems, frequently without prior assessment of their potential effects on biota. Recently, growing concern over these problems has led to a large number of studies of such polluted ecosystems (Rodgers et al., 1980; Abaychi \& Mustafa, 1998; Bilos et al., 1998; Baudrimont et al., 2003; Marie et al., 2006; Peltier et al., 2008). Compared to freshwater and marine ecosystems, tidal freshwater wetlands have been less studied, and a deficit of ecological, ecotoxicological and biological knowledge still exists in these ecosystems, mainly due to their unique characteristics (Rundle et al., 1998; Attrill \& Rundle, 2002; Sousa et al., 2008a). These transitional areas are subjected to several environmental threats, such as reservoir construction, eutrophication, chemical pollution, degradation of water quality, dredging and other hydrological modifications (Ysebaert et al., 2003). Therefore, these ecosystems need special attention particularly because they are facing a considerable risk of biodiversity loss, primarily for those species particularly sensitive to chemical and abiotic stress.

Estuaries from the northwest to south coast of Portugal, including the Douro estuary, "Ria de Aveiro", Tagus, Sado and "Ria Formosa," are contaminated by anthropogenic metals (Caetano et al., 2002; Monterroso et al., 2003; Mucha et al., 2003; Caeiro et al., 2005; França et al., 2005). The Minho estuary (northwest Iberian Peninsula) was until recently considered "clean" and showed no indications of significant anthropogenic contamination (INAG, 1999; Paiva et al., 2003). However, recent research by Moreno et al. (2005) and Reis et al. (2009) has found metal enrichment in sediments from this estuary.

Mussels (e.g., Mytilus spp.), clams (e.g., Mya arenaria and Spisula solida), oysters (e.g., Crassostreas gigas) and other bivalve species have biological and ecological characteristics that make them useful biomonitors of contamination. These characteristics include their wide geographical distribution, ease of collection, abundance, ability to accumulate a vast range of contaminants and low mobility or sessile nature (Rodgers et al., 1980; Araujo et al., 1993; Abaychi \& Mustafa, 1998; Bilos et al., 1998; Baudrimont et al., 2003; Marie et al., 2006; Peltier et al., 2008; Reis et al., 2011). These species are likely to reflect changes in contamination levels in their habitat over time and have therefore been widely used in monitoring studies to assess the levels and effects of contamination (Marie et al., 2006; Peltier et al., 2008; Reis et al., 2011).

The Asian clam Corbicula fluminea has invaded several aquatic ecosystems around the world, including the Minho estuary. Following invasion, $C$. fluminea are sometimes able to coexist with native species, but in several situations, they have caused the considerable decline of native bivalve species (Sousa et al., 2008b). C. fluminea may be an ideal species in which to study contamination levels in aquatic ecosystems for several reasons: (i) it has become a major component of benthic communities, with a wide spatial distribution (Sousa et al., 2008b); (ii) it may be found in both pristine and polluted environments; (iii) it may be very abundant (Phelps, 1994; Sousa et al., 2008c, d, e); (iv) it has a great filtration capacity, allowing for the uptake of high amounts of contaminants; and (v) the size of adults facilitates easy dissection and 
Metal concentrations in sediments and in Corbicula fluminea from the Minho estuary 163

separation of the main organs, enabling specific analyses (Inza et al., 1997).

The main objectives of this research were as follows:

(i) to assess metal $(\mathrm{Cd}, \mathrm{Cr}, \mathrm{Cu}, \mathrm{Fe}, \mathrm{Ni}, \mathrm{Pb}$ and $\mathrm{Zn}$ ) concentrations in sediments and in the soft tissues of $C$. fluminea in the Minho estuary, which will enable the construction of a database for comparison to future research;

(ii) to assess the spatial variation of metal bioavailability in the Minho estuary;

(iii) to assess the potential use of $C$. fluminea as a biomonitor of metal contamination in the Minho estuary; and (iv) to compare different ecological quality classifications of the Minho estuary.

\section{MATERIALS AND METHODS}

\section{Study Area}

The Minho estuary is located in northwest (NW) Iberian Peninsula, draining North-NortheastSouth-Southwest (NNE-SSW) into the Atlantic Ocean (Fig. 1). This estuary is partially mixed and, during the period of high floods, tends to evolve toward a salt wedge estuary (Antunes \&

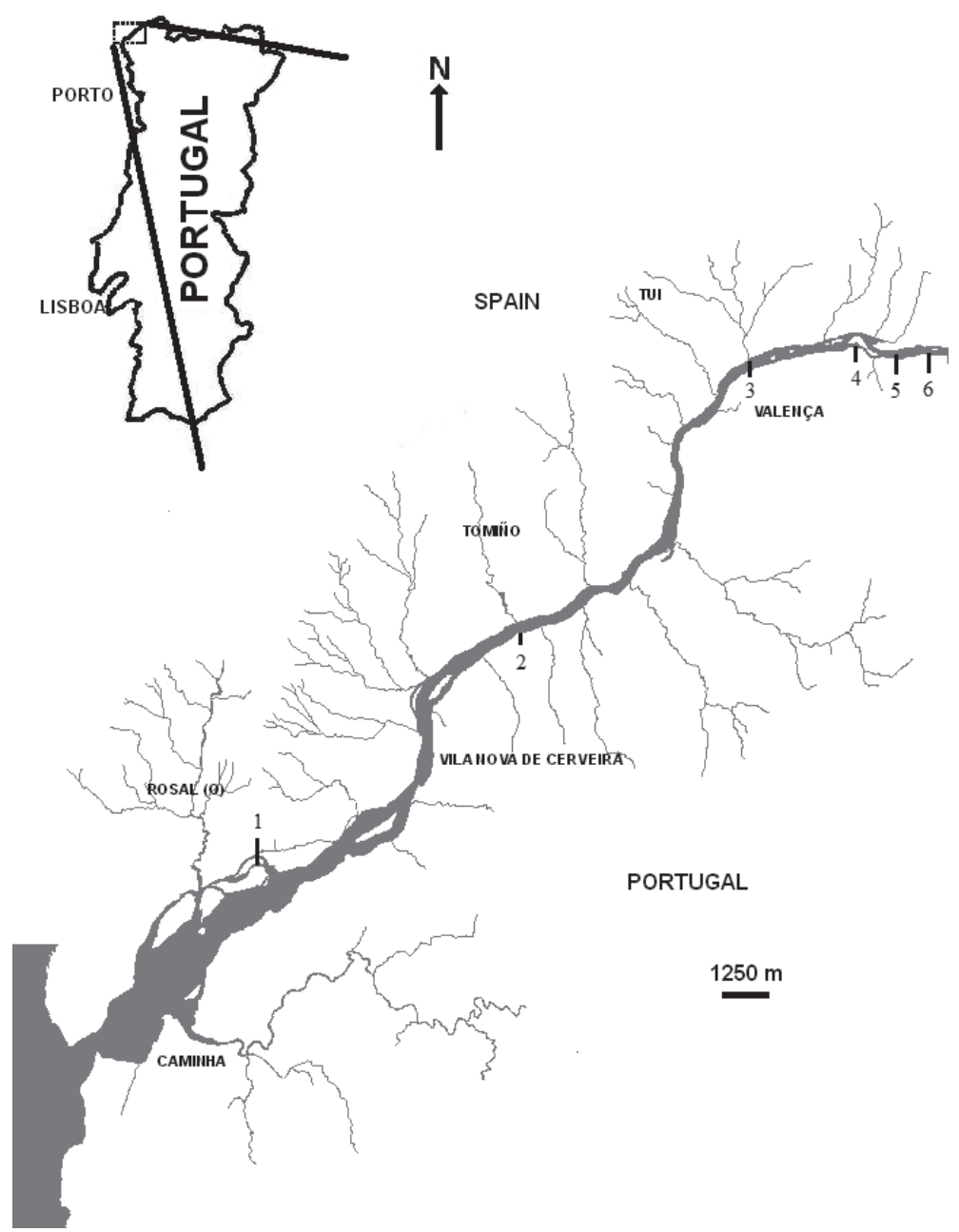

Figure 1. Location of sampling sites (sites 1 to 6) in the Minho estuary (Northwest Iberian Peninsula). Localización de los sitios de muestreo (sitios 1 a 6) en el estuario del Miño (Noroeste de la Península Ibérica). 
Table 1. Metal concentrations (mg/kg, dry wt. basis) obtained in SRM 2702 and SRM 2976, certified for inorganic elements in marine sediments and mussel tissue of Mytilus galloproincialis, respectively. Concentraciones de metales (mg/kg, peso seco) obtenidos en SRM 2702 y SRM 2976 certificados para elementos inorgánicos en sedimentos marinos y tejidos del mejillón Mytilus galloproincialis respectivamente.

\begin{tabular}{ccccc}
\hline $\begin{array}{c}\text { Element } \\
(\mathrm{mg} / \mathrm{kg})\end{array}$ & \multicolumn{2}{c}{ SRM 2702 } & \multicolumn{2}{c}{ SRM 2976 } \\
$($ Certified $)$ & (Obtained) & $0.82 \pm 0.02$ \\
$\mathrm{Cd}$ & $0.817 \pm 0.011$ & $0.956 \pm 0.049$ & $0.82 \pm 0.16$ & $0.55 \pm 0.02$ \\
$\mathrm{Cr}$ & $352 \pm 22$ & $359 \pm 63$ & $0.50 \pm 0.16$ & $3.98 \pm 0.20$ \\
$\mathrm{Cu}$ & $117.7 \pm 5.6$ & $102.4 \pm 2.4$ & $4.02 \pm 0.33$ & $0.93 \pm 0.11$ \\
$\mathrm{Ni}$ & $75.4 \pm 1.5$ & $83.7 \pm 1.1$ & $0.93 \pm 0.12$ & $1.07 \pm 0.12$ \\
$\mathrm{~Pb}$ & $132.8 \pm 1.1$ & $114.2 \pm 1.5$ & $1.19 \pm 0.18$ & $148 \pm 18$ \\
$\mathrm{Zn}$ & $485.3 \pm 4.2$ & $485 \pm 20$ & $137 \pm 13$ & \\
\hline
\end{tabular}

Dias, 2005; Sousa et al., 2005). The Minho River drains a hydrological basin of $17,080 \mathrm{~km}^{2}, 95 \%$ of which is in Spain and $5 \%$ in Portugal. This river is $300 \mathrm{~km}$ long (the last $70 \mathrm{~km}$ mark the Portuguese/Spanish border) and has a mean annual freshwater discharge of $300 \mathrm{~m}^{3} / \mathrm{s}$ (Sousa et al., 2005). The influence of spring tides extends approximately $40 \mathrm{~km}$ upstream, comprising a total estuarine area of $23 \mathrm{~km}^{2}$ (Sousa et al., 2005).

In the last decade, several studies have been conducted on the macroinvertebrates and fish species in this estuary to characterise the major environmental and ecological processes (Antunes \& Dias, 2005; Sousa et al., 2005; 2006a, b; 2007a, b; 2008a, e; Costa-Dias et al., 2010a, b).

\section{Reagents and Materials}

All reagents used in this work were at least of pro analysis or equivalent grade, without further purification: $\mathrm{HNO}_{3}$ (Fluka, pro analysis). Solutions were prepared with high-purity water from a Milli-Q system (conductivity: $0.054 \mu \mathrm{S} / \mathrm{cm}$ at $25^{\circ} \mathrm{C}$ ). The metal standard solutions used in the analysis were prepared daily by weight from a stock solution of $1000 \mathrm{mg} / \mathrm{L}$ (Fluka, pro analysis). All sampling and treatment materials had been decontaminated in a nitric acid solution (20\%, v/v) for at least for $24 \mathrm{~h}$, washed with deionised water (conductivity $<0.066 \mu \mathrm{S} / \mathrm{cm}$ at $25^{\circ} \mathrm{C}$ ) and dried in an oven

\section{Collection and treatment of samples}

Sediments and adult Asian clams (C. fluminea) were collected at six sites in the Minho estuary in April 2007 (Fig. 1). One sediment sample per site was prepared and analysed for granulometry and organic matter (OM) content, as previously described in Sousa et al. (2005, 2006a). To test for metal contamination, three sediment replicates per site were collected and transported to the laboratory within two hours. Samples were dried at room temperature until constant weight and were sieved though 2-mm nylon nets to remove large stones and gravel (Reis et al., 2009). Afterwards, $300 \mathrm{mg}$ of each sediment replicate was digested with $5 \mathrm{ml}$ of concentrated $\mathrm{HNO}_{3}$ in a domestic

Table 2. Metal concentrations ( $\mathrm{mg} / \mathrm{kg}$, dry wt. basis) obtained in sediments from the Minho estuary. Concentraciones de metales ( $\mathrm{mg} / \mathrm{kg}$, peso seco) obtenidos en sedimentos procedentes del rio Miño.

\begin{tabular}{cccccccc}
\hline $\begin{array}{c}\text { Element } \\
(\mathrm{mg} / \mathrm{kg})\end{array}$ & $\begin{array}{c}\text { Limit of } \\
\text { detection }\end{array}$ & 1 & 2 & 3 & \multicolumn{5}{c}{ Sampling Site } \\
$\mathrm{Cd}$ & 0.011 & $0.025 \pm 0.006$ & $0.03 \pm 0.01$ & $0.113 \pm 0.002$ & $0.20 \pm 0.02$ & $0.36 \pm 0.02$ & $0.21 \pm 0.02$ \\
$\mathrm{Cr}$ & 0.055 & $10 \pm 2$ & $7 \pm 1$ & $12 \pm 1$ & $15 \pm 1$ & $16 \pm 2$ & $11.7 \pm 0.6$ \\
$\mathrm{Cu}$ & 2.62 & $2.7 \pm 0.1$ & $3 \pm 1$ & $12.7 \pm 0.4$ & $17.4 \pm 0.9$ & $24.6 \pm 0.7$ & $14.8 \pm 0.7$ \\
$\mathrm{Ni}$ & 2.53 & $11 \pm 2$ & $7.3 \pm 0.6$ & $20 \pm 2$ & $26 \pm 1$ & $45 \pm 2$ & $31.1 \pm 0.8$ \\
$\mathrm{~Pb}$ & 0.24 & $4.8 \pm 0.5$ & $4.1 \pm 0.6$ & $11.3 \pm 0.2$ & $8.2 \pm 0.5$ & $15 \pm 2$ & $7.5 \pm 0.3$ \\
$\mathrm{Zn}$ & 6.7 & $37.3 \pm 0.9$ & $38 \pm 4$ & $78.2 \pm 0.9$ & $96 \pm 5$ & $110 \pm 5$ & $108 \pm 3$ \\
\hline
\end{tabular}


microwave system (model NE-1037, Panasonic) using Parr teflon reactors (model 4782, Parr) at high pressure following the method of Reis et al. (2009).

Thirty-five adult individuals of $C$. fluminea (20-25-mm shell length) were collected at each site and transported to the laboratory in plastic bags within two hours after their collection. In the laboratory, soft tissues were isolated and pooled samples of ten clams were lyophilised (Labconco's lyophiliser, 48 hours). As described above, $300 \mathrm{mg}$ of each tissue replicate was digested with diluted $\mathrm{HNO}_{3}$ solution in a microwave following the method of Reis \& Almeida (2008).

\section{Determination of metals in samples}

Metals $(\mathrm{Cd}, \mathrm{Cr}, \mathrm{Cu}, \mathrm{Fe}, \mathrm{Ni}, \mathrm{Pb}$ and $\mathrm{Zn}$ ) were assessed using Atomic Absorption Spectrometry (SpectrAA 220 FS, Varian) with flame (Marck 7, Varian) and electrothermal atomisation (Autosampler GTA 110, Varian), depending on the metal concentrations, with a deuterium background correction $\left(\mathrm{D}_{2}-\mathrm{BG}\right)$ system using APHA recommendations (APHA, 1998b, c).

For each solution analysed, Varian software was programmed to give values with precisions below $10 \%$ between readings, in a maximum of four readings per replicate, to assure reproducibility of the measurements (Varian, 1988). External calibrations for each metal were carried out with aqueous standards using the operating conditions recommended by Varian manuals (Varian, 1988, 1989). Blank solutions were prepared following the appropriate sample treatment and metal concentrations in blank solutions were always below the limit of detection of the analytical procedure for all elements (APHA 1998d). The limits of detection were calculated using APHA recommendations (APHA, 1998d).

The Standard Reference Material, SRM 2702, certified for "inorganics in marine sediments" was used to check the suitability of the analytical procedure for estuarine sediments (Reis et al.,

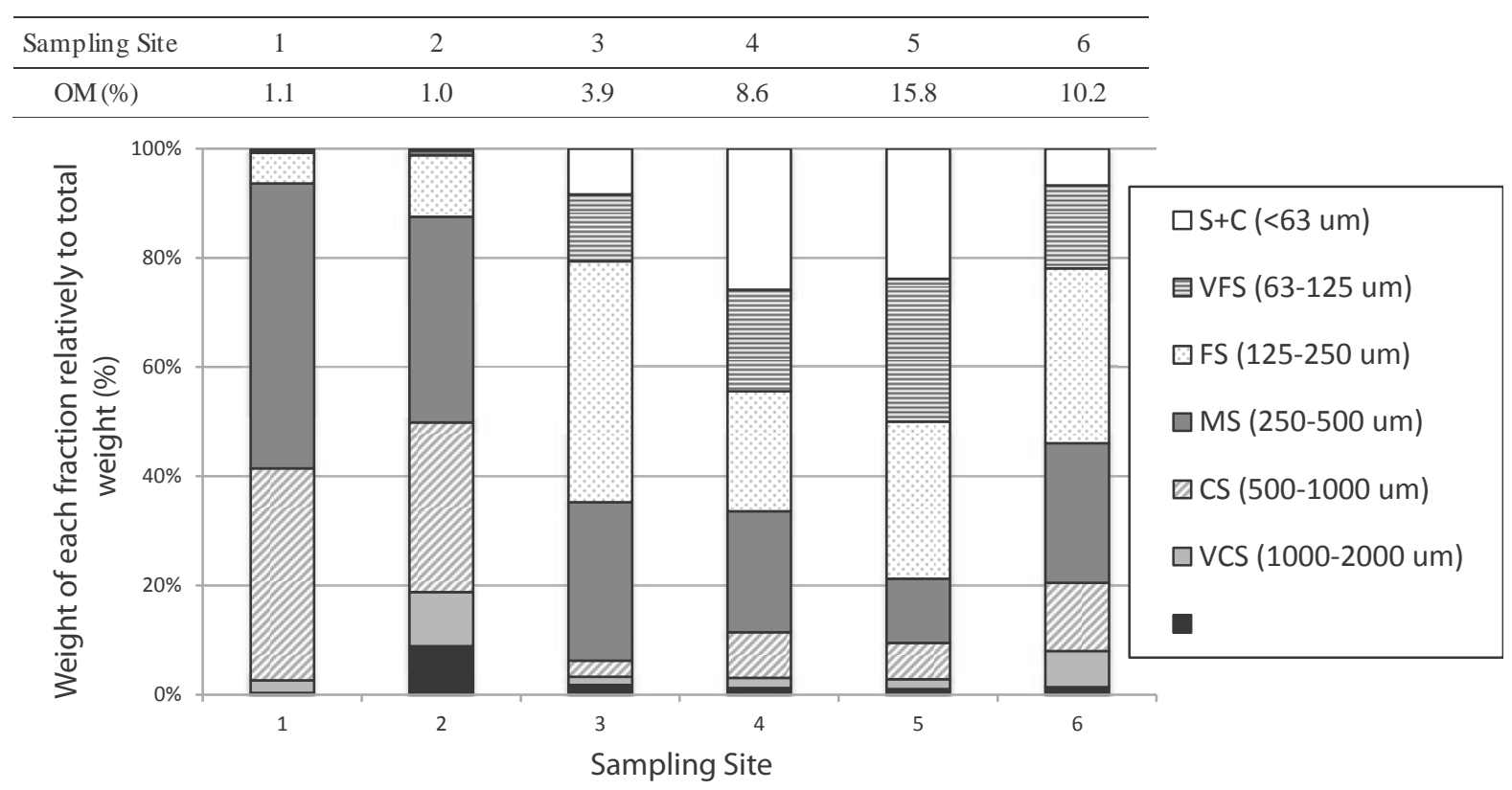

Figure 2. Percentage of organic matter $(\mathrm{OM})$ content and granulometry in sediments from the Minho estuary. Fractions: Silt and Clay $(\mathrm{S}+\mathrm{C},<63 \mu \mathrm{m})$; Very Fine Sand (VFS, 63-125 $\mu \mathrm{m}$ ); Fine Sand (FS, 125-250 $\mu \mathrm{m}$ ); Medium Sand (MS, 250-500 $\mu \mathrm{m})$; Coarse

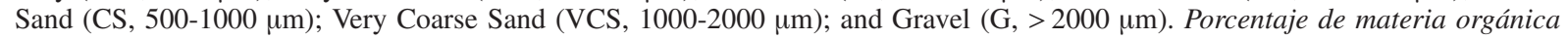
$(O M)$ y granulometría en sedimentos procedentes del estuario del Miño. Leyendas de cada granulometría: limo y arcilla (S+C,

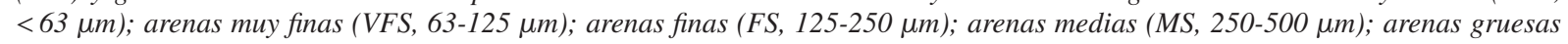

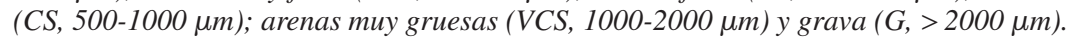


2009). The analyses of SRM 2702 revealed satisfactory recoveries for all elements that were higher than $86 \%$ (Table 1). Recovery values below $100 \%$ were expected for some metals because the $\mathrm{HNO}_{3}$ digestion of the sediments only allows for the determination of total-recoverable metal contents (US-EPA, 1994). This method has the advantage of being a strong acid digestion that dissolves all elements that could become "environmentally available" and that have ecotoxicological potential (US-EPA, 1994).

The Standard Reference Material, SRM 2976, certified for "trace elements and methylmercury in mussel tissues" was used to check the suitability of the entire analytical procedure for clam tissues (Reis \& Almeida 2008; Reis et al. 2012a,b). The analyses of SRM 2976 also revealed satisfactory recoveries for all elements that were higher than $90 \%$ (Table 1).

For each sediment and tissue sample, three replicates were analysed, and the respective average and standard deviation were calculated (APHA, 1998d; Reis \& Almeida, 2008; Reis et al., 2009, 2012a, b). To compare contaminant concentrations among sites, ANOVA and multivariate analyses were applied using the Classification CLUSTER, based on the Euclidean distance matrix, available in the PRIMER package (Clarke \& Warwick, 2001).

\section{RESULTS AND DISCUSSION}

\section{Abiotic characterisation of the sediments}

The OM content and granulometry of the sediments from the different sites showed spatial variation (Fig. 2). The OM contents and silt and clay fractions $(\mathrm{S}+\mathrm{C},<63 \mu \mathrm{m})$ were significantly higher in sites 3-6 (upstream sites) than in sites 1 and 2 (downstream sites), in which the fractions of median (MS) and coarse sand (CS) were dominant. The OM contents measured in this study (1.0-15.8\%) were higher than those previously reported by Maze et al. (1993) in the Minho estuary $(<0.250-0.624 \%)$ and by Reis et al. (2009) in the Minho saltmarsh areas (1.3-10.7\%). The percentage of $\mathrm{OM}$ in the sediments was significantly positively correlated with their fine frac- tions $(\mathrm{S}+\mathrm{C},<63 \mu \mathrm{m})$, which can be explained by smooth hydrodynamic conditions, promoting the retention of particles, and by the presence of plants (Reis et al., 2009). The Minho estuary followed this tendency with high accumulations of detritus from the margins after the winter period, mainly in upstream sites. Indeed, site 5 showed high percentages of fine sediments and OM due to the fact that it is located in a sheltered area. In contrast, sites 1 and 2, located in downstream areas, showed coarser sediments and lower percentages of OM.

\section{Metal concentrations of the sediments}

The metal $(\mathrm{Cd}, \mathrm{Cr}, \mathrm{Cu}, \mathrm{Fe}, \mathrm{Ni}, \mathrm{Pb}$ and $\mathrm{Zn})$ concentrations of the sediments from the Minho estuary are shown in Table 2. Metals in sediment samples varied spatially $(p<0.05)$, and the concentrations (dry wt. basis) ranged from 0.025 $0.36 \mathrm{mg} \mathrm{Cd} / \mathrm{kg}, 7-16 \mathrm{mg} \mathrm{Cr} / \mathrm{kg}, 2.7-24.6 \mathrm{mg}$ $\mathrm{Cu} / \mathrm{kg}, 7.3-45 \mathrm{mg} \mathrm{Ni} / \mathrm{kg}, 4.1-15 \mathrm{mg} \mathrm{Pb} / \mathrm{kg}$ and $37.3-110 \mathrm{mg} \mathrm{Zn/kg}$.

The CLUSTER analysis based on the Euclidean distance index, using data of granulometry, $\mathrm{OM}$ contents and metal concentrations, identified two distinct groups of sites (Fig. 3): Group A and Group B. Group A was composed of only site 1 (downstream site), which had sediments with the lowest metal concentrations, low OM contents and mainly median, coarse and very coarse sand fractions (i.e., site 1 had concentrations of $\mathrm{Cd}, \mathrm{Cu}$ and $\mathrm{Ni}$ approximately 5-10 times lower than sites 4, 5 and 6). Group B was composed of sites 2-6 (upstream sites), which had high metal concentrations, high OM contents and sediments composed mainly of silt and clay, very fine and fine sand fractions. These finer granulometry and higher OM contents allow sediments to retain more metals by adsorption and complexation, although the more sensitive redox elements can be remobilised during the degradation of OM (Monterroso et al., 2003). This CLUSTER analysis showed that the natural characteristics of sediments highly influence the concentrations of metals they retain. Indeed, the natural characteristics (granulometry and OM contents) of sediments from both groups can be considered the primary 
reason for the higher metal concentrations observed in sites 2-6 relative to site 1 .

The metal concentrations in sediments from the main Portuguese estuaries reported over the years are shown in Table 3. Although our study measured total-recoverable metal concentrations, comparisons with total-total metal concentrations from other studies can be considered acceptable because our recovery percentages in SRM 2702 were higher than $86 \%$ (Table 1). To reflect the variation, we observed in metal concentrations across sediment types; comparisons of our data to other studies of the Minho estuary should also take into account the spatial and seasonal variation in sediment characteristics. Our metal concentrations were similar to those observed by Paiva et al. (1993), INAG (1999) and Reis et $a l$. (2009) and lower than the concentrations reported by Moreno et al. (2005) (Table 3). Moreno et al. (2005) found that the most sheltered areas of the Minho estuary, which coincided with our sites 5 and 6 , retained the highest concentrations of $\mathrm{Cr}, \mathrm{Cu}, \mathrm{Ni}$ and $\mathrm{Zn}$ and were associated with anthropogenic contamination. Additionally, our metal concentrations were lower than those reported in the other main Portuguese estuaries, suggesting relatively low metal contamination of the Minho estuary (Table 3).
In 2004, the Norwegian Pollution Control Authorities developed a guideline for environmental risk assessment of marine sediments to be used as a supportive tool in the decision making processes on remediation of polluted sediments (Bakke et al., 2010). In 2007, the Norwegian Pollution Control Authorities modified the approach to categorise environments as one of five environmental quality classes based on the concentration of contaminants (Bakke $e t$ al., 2010). These environmental quality classes were based on ecotoxicology and followed the principles of contaminant risk assessment of the European Community (Bakke et al., 2010). These guidelines included 50 inorganic and organic compounds, which were focused on toxicity to aquatic organisms as well as impact on human health (Bakke et al., 2010). In 2010, the Norwegian classification system changed from one based on the distribution of contaminant concentrations to one based on environmental effects and closely linked to the risk assessment principles of the European Union. This final ecological classification system is consistent with the Norwegian guidelines for risk assessment of marine sediments and represents a useful tool for marine environmental management (Bakke et al., 2010). This Norwegian approach

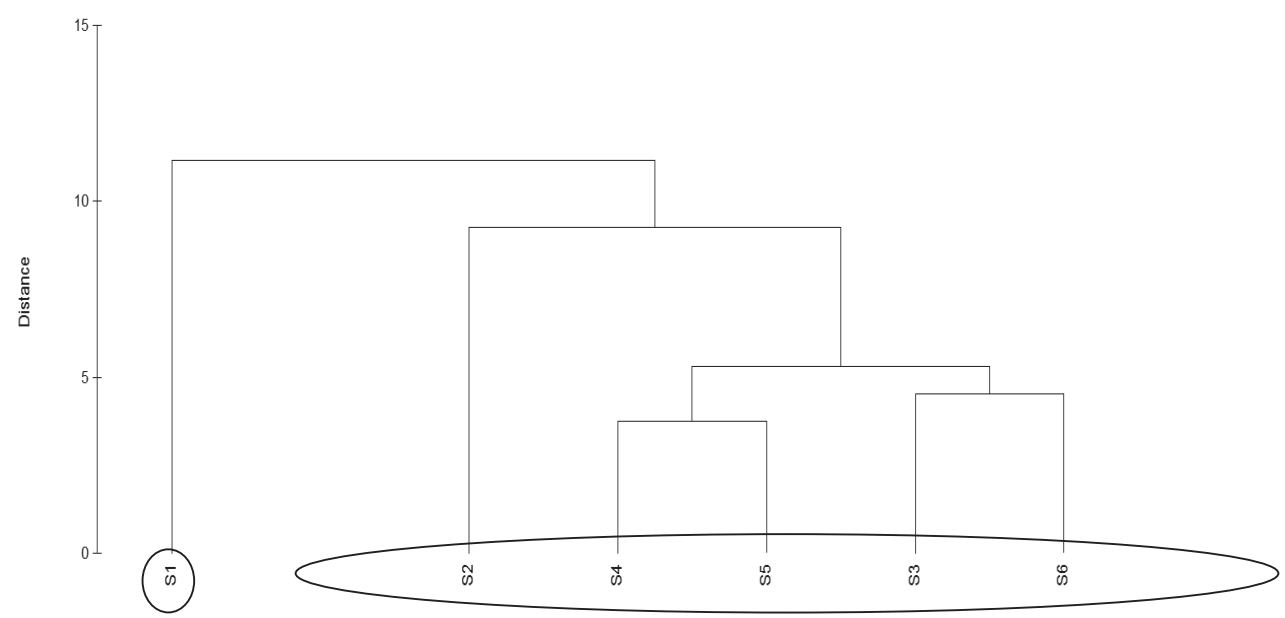

Figure 3. Groups of sampling sites from the Minho estuary based on Euclidean distance, considering granulometry, OM contents and metal concentrations of sediments. Agrupaciones de estaciones en el estuario del Miño basados en distancias euclideas, considerando la granulometría, contenido en materia orgánica y concentración de metales del sedimento. 
is preferable to the United States Environmental Protection Act and Canadian sediment quality guidelines (SQGs) because it represents a final agreement established and ratified during the Oslo-Paris (OSPAR) Convention involving 14 European countries (Belgium, Denmark, Finland, France, Germany, Iceland, Ireland, Luxembourg, Netherlands, Norway, Portugal, Sweden, Switzerland and the United Kingdom) and has been approved by the European Community management (Bakke et al., 2010). Thus, these guidelines for sediments can be used in ecological quality classifications in different coastal and estuarine areas in Europe, including Portugal (Region IV) (Bakke et al., 2010). Using the Norwegian Pollution Control
Authority metal concentrations guidelines for sediments (Table 3), we determine the first ecological quality classification of the Minho estuary as a coastal ecosystem of "Class I/IIBackground/Good” quality (Bakke et al., 2010).

This preliminary ecological quality classification of the Minho estuary, based on metal concentrations in sediments, would be strengthened by confirmation using a metal biomonitor species, such as C. fluminea, Chthamalus montagui or Pollicipes (Reis et al., 2012a,b). Because biomonitor species vary in their metal bioaccumulation factors (BAFs), it is important to assess the suitability of a given biomonitor species in the particular ecosystem of interest prior to a contamination assessment. Reis et al. (2012a,b)

Table 3. A. Range of metal concentrations ( $\mu \mathrm{g} / \mathrm{kg}$ or $\mathrm{mg} / \mathrm{kg}$, dry wt. basis) in sediments from the Minho estuary. B. Range of metal concentrations $(\mu \mathrm{g} / \mathrm{kg}$ or $\mathrm{mg} / \mathrm{kg}$, dry wt. basis) in sediments from other Portuguese wetlands. C. Ecological quality classification of coastal ecosystems based on sediment metal concentrations according to the Norwegian Pollution Control Authority (Bakke et al., 2010). A. Intervalos de concentración de metales ( $\mu \mathrm{g} / \mathrm{kg}$ o $\mathrm{mg} / \mathrm{kg}$, peso seco) en sedimentos procedentes del estuario del Miño. $B$. Intervalos de concentración de metales ( $\mu \mathrm{g} / \mathrm{kg}$ o $\mathrm{mg} / \mathrm{kg}$, peso seco) en sedimentos procedentes de otros humedales portugueses. C. Clasificación ecológica de los ecosistemas costeros basada en las concentraciones de metales en sedimentos de acuerdo a la Norwegian Pollution Control Authority (Bakke et al., 2010).

\begin{tabular}{|c|c|c|c|c|c|c|}
\hline Location & $\begin{array}{c}\text { Cd } \\
(\mu \mathrm{g} / \mathrm{kg})\end{array}$ & $\begin{array}{c}\mathrm{Cr} \\
(\mathrm{mg} / \mathrm{kg})\end{array}$ & $\begin{array}{c}\mathrm{Cu} \\
(\mathrm{mg} / \mathrm{kg})\end{array}$ & $\begin{array}{c}\mathrm{Ni} \\
(\mathrm{mg} / \mathrm{kg})\end{array}$ & $\begin{array}{c}\text { Pb } \\
(\mathrm{mg} / \mathrm{kg})\end{array}$ & $\begin{array}{c}\mathrm{Zn} \\
(\mathrm{mg} / \mathrm{kg})\end{array}$ \\
\hline Minho estuary (our study) & $25-360$ & 7.0-16 & $2.7-24.6$ & $7.3-45$ & $4.1-15$ & $37-110$ \\
\hline \multicolumn{7}{|l|}{ A } \\
\hline \multicolumn{7}{|c|}{ Range of metal concentrations observed in sediments from Minho estuary } \\
\hline Minho Estuary [Paiva et al., 1993] & - & $5-56$ & $5-29$ & $9-30$ & $18-50$ & $22-94$ \\
\hline Minho Estuary [Reis et al., 2009] & $<100$ & $6-15$ & $3.2-7.5$ & $0.9-9.3$ & $9-16$ & $33-44$ \\
\hline Minho Estuary [Moreno et al., 2005] & - & $20-62$ & $9-36$ & $9-47$ & $12-42$ & $32-157$ \\
\hline Minho Saltmarsh [Moreno et al., 2005] & - & $26-116$ & $13-91$ & $9-76$ & $21-80$ & $53-160$ \\
\hline Minho Saltmarsh [Reis et al., 2009] & $21-265$ & $7.0-20$ & $2.8-22$ & $3.6-22$ & $4.8-15$ & $38-92$ \\
\hline \multicolumn{7}{|l|}{ B } \\
\hline \multicolumn{7}{|c|}{ Range of metal concentrations observed in sediments from several Portuguese wetlands } \\
\hline Douro Estuary [Mucha et al., 2003, 2004] & $70-280$ & $1-94$ & $1-229$ & $11-26$ & $0.3-192$ & $6-457$ \\
\hline Ria de Aveiro [Monterroso et al., 2003] & $40-1550$ & - & $3-46$ & - & $6-26$ & $51-589$ \\
\hline Tagus Estuary [Caçador et al., 1996; França et al., 2005] & $1700-5900$ & $35-55$ & $28-89$ & $25-35$ & $65-199$ & $168-427$ \\
\hline Sado Estuary [Caeiro et al., 2005] & $200-8000$ & $0.6-63$ & $1-191$ & - & $2-69$ & $2-507$ \\
\hline Ria Formosa [Padinha et al., 2000; Caetano et al., 2002] & $40-6300$ & $11-64$ & $1.1-59$ & $9-24$ & $11-46$ & $7-167$ \\
\hline \multicolumn{7}{|l|}{$\mathrm{C}$} \\
\hline \multicolumn{7}{|l|}{ Ecological quality of the ecosystem [Bakke et al., 2010] } \\
\hline Class I-Background & $<250$ & $<70$ & $<35$ & $<30$ & $<30$ & $<150$ \\
\hline Class II-Good & $250-2,600$ & $70-560$ & $35-51$ & $30-46$ & $30-83$ & $150-360$ \\
\hline Class III-Moderate & $2,600-15,000$ & $560-5,900$ & $51-55$ & $46-120$ & $83-100$ & $360-590$ \\
\hline Class IV-Bad & $15,000-140,000$ & $5,900-59,000$ & $55-220$ & $120-840$ & $100-720$ & $590-4,500$ \\
\hline Class V-Very Bad & $>140,000$ & $>59,000$ & $>220$ & $>840$ & $>720$ & $>4,500$ \\
\hline
\end{tabular}


have previously shown that $C$. montagui and $P$. pollicipes can be used as biomonitors of metal contamination along the NW coast of Portugal, including in the Minho estuary. They obtained significant linear correlations $(p<0.05)$ between metal concentrations in water samples and those accumulated in biomonitor tissues. However, they did not assess the suitability of C. fluminea, which may also be an appropriate biomonitor species of metal contamination in the Minho estuary and aquatic ecosystems worldwide.

\section{Metal concentrations of $C$. fluminea}

The metal concentrations measured in the soft tissues of the Asian clam C. fluminea from the Minho estuary are shown in Table 4. Total-total metal concentrations were considered acceptable, as the analytical methodology obtained recovery percentages in SRM 2976 higher than $90 \%$ (Table 1). Metal concentrations (dry wt. basis) in C. fluminea ranged from $1.1-2.5 \mathrm{mg} \mathrm{Cd} / \mathrm{kg}$, $1.0-1.8 \mathrm{mg} \mathrm{Cr} / \mathrm{kg}, 34-71 \mathrm{mg} \mathrm{Cu} / \mathrm{kg}, 5.8-11 \mathrm{mg}$ $\mathrm{Ni} / \mathrm{kg}, 0.45-1.3 \mathrm{mg} \mathrm{Pb} / \mathrm{kg}$ and $136-161 \mathrm{mg} \mathrm{Zn/kg}$.

Metal concentrations in $C$. fluminea also showed significant spatial variation $(p<0.05)$. The lowest metal concentrations were found in site $5(\mathrm{Cd}, \mathrm{Cr}$ and $\mathrm{Zn})$ and in sites 1,4 and $6(\mathrm{Cu}, \mathrm{Ni}$ and $\mathrm{Pb}$, respectively). The greatest metal concentrations were found in site 3 $(\mathrm{Cr}, \mathrm{Cu}, \mathrm{Ni}$ and $\mathrm{Zn})$ and in sites 1 and $4(\mathrm{~Pb}$ and $\mathrm{Cd}$, respectively). Thus, C. fluminea from downstream areas (sites 1-3) bioaccumulated greater concentrations of metals than those from upstream areas (sites 4-6), most likely as a result of higher anthropogenic influences in the lower estuarine areas, which were not revealed by our sediment analysis. Downstream areas of the Minho estuary are located near the cities of Caminha and Vila Nova de Cerveira, which may be discharging untreated domestic and industrial effluents into the waters of the Minho estuary. Overall, it appears that there is greater metal availability to organisms in downstream areas than upstream areas of the Minho estuary, and similar significant spatial variations should also be expected for metal bioavailability.

Because this study only included six sampling sites, we cannot extrapolate our findings to the whole ecosystem. From our data, it appears that the high metal concentrations found in sediments, particularly in sites 5 and 6 , had no significant effects on $C$. fluminea; therefore, the Minho estuary should be considered "clean" of metals. However, previous studies have found evidence of metal contamination in C. fluminea from the Minho estuary, particularly by $\mathrm{Cd}$ and $\mathrm{Cu}$ (Table 5 ). For example, $C$. fluminea from the Minho estuary were found to have 10 times greater $\mathrm{Cd}$ and $\mathrm{Cu}$ concentrations than $C$. fluminea from CazauxSanguinet Lake in France (Baudrimont et al., 1997). At the present time, the source of this potential metal contamination remains unidentified.

The Norwegian Pollution Control Authority has also developed guidelines for classifying the ecological quality of coastal ecosystems using biomonitor species (Molvaer et al., 1997). There are currently not guidelines specific to C. fluminea, but using the guidelines (SFT TA-1467/1997) for blue mussels Mytilus edulis (Table 5), metal concentrations in C. fluminea suggest that the Minho estuary be classified as "Class II/III - Moderately/Remarkably Polluted" because of their high $\mathrm{Cu}$ concentrations

Table 4. Metal concentrations (mg/kg, dry wt. basis) obtained in soft tissues of $C$. fluminea from the Minho estuary. Concentraciones de metales ( $\mathrm{mg} / \mathrm{kg}$, peso seco) obtenidas en tejidos blandos de C. fluminea procedentes del estuario del Miño.

\begin{tabular}{cccccccc}
\hline $\begin{array}{l}\text { Element } \\
(\mathrm{mg} / \mathrm{kg})\end{array}$ & $\begin{array}{c}\text { Limit of } \\
\text { detection }\end{array}$ & 1 & 2 & 3 & \multicolumn{5}{c}{ Sampling Site } \\
\hline $\mathrm{Cd}$ & 0.003 & $2.3 \pm 0.2$ & $1.8 \pm 0.1$ & $1.5 \pm 0.1$ & $2.5 \pm 0.3$ & $1.1 \pm 0.2$ & $2.1 \pm 0.3$ \\
$\mathrm{Cr}$ & 0.033 & $1.6 \pm 0.6$ & $1.6 \pm 0.1$ & $1.8 \pm 0.1$ & $1.4 \pm 0.2$ & $1.0 \pm 0.2$ & $1.3 \pm 0.3$ \\
$\mathrm{Cu}$ & 3.31 & $34 \pm 2$ & $40 \pm 1$ & $71 \pm 3$ & $61 \pm 1$ & $44 \pm 8$ & $65 \pm 9$ \\
$\mathrm{Ni}$ & 0.067 & $8 \pm 2$ & $7.3 \pm 0.3$ & $11 \pm 2$ & $5.8 \pm 0.5$ & $8 \pm 2$ & $9 \pm 2$ \\
$\mathrm{~Pb}$ & 0.064 & $1.3 \pm 0.2$ & $1.03 \pm 0.06$ & $1.0 \pm 0.1$ & $1.1 \pm 0.1$ & $0.7 \pm 0.2$ & $0.45 \pm 0.09$ \\
$\mathrm{Zn}$ & 6.7 & $141 \pm 4$ & $159 \pm 4$ & $161 \pm 5$ & $141 \pm 6$ & $136 \pm 5$ & $152 \pm 10$ \\
\hline
\end{tabular}


(Molvaer et al., 1997). In conclusion, C. fluminea proved to be a useful biomonitor species of metal contamination in the Minho estuary.

The distribution of $C$. fluminea continues to grow, and this species can now be found in several countries, including Argentina, the United States, France and Iraq, where it also has the potential of being used as a biomonitor species of metal contamination (Abaychi \& Mustafa, 1998; Bilos et al., 1998; Marie et al., 2006; Peltier et al., 2008). Compared to C. $f l u$ minea from these other countries, Portuguese $C$. fluminea were found to have similar or higher metal concentrations in their tissues, confirming that the Minho estuary has experienced metal contamination (Table 5).

In summary, this study showed that metal concentrations in sediments and in soft tissues of $C$. fluminea from the Minho estuary (Northwest Iberian Peninsula) were spatially variable. Generally, C. fluminea from upstream estuarine areas had bioaccumulated lower metal concentrations than those from downstream areas, revealing different levels of metal bioavailability along the Minho estuary. Metals in the Minho estuary were associated not only with natural sources but also with anthropogenic sources. Metal concentrations measured in sediments allowed us to determine the first ecological quality classification of Minho estuary as "Class I/II-Background/Good." However, high Cu concentrations accumulated by $C$. fluminea suggest that the Minho estuary should instead be classified as "Class II/III-Moderately/Remarkably Polluted." The primary contributions of this research are that $C$. fluminea can be used as a biomonitor of metal contamination in the Minho estuary and can be used to classify the ecological quality of estuarine ecosystems worldwide.

The metal concentrations that we have reported in both sediments and $C$. fluminea from the Minho estuary can be used as a baseline and will be incorporated into a database for comparison to future research. Future research should investigate regulation mechanisms and physiological parameters, such as uptake rate constants

Table 5. A. Metal concentrations ( $\mathrm{mg} / \mathrm{kg}$, dry wt. basis) obtained in soft tissues of $C$. fluminea in other similar studies. B. Ecological quality classification of coastal ecosystems based on blue mussel Mytilus edulis soft tissues metal concentrations (SFT TA-1467/1997) according to the Norwegian Pollution Control Authority (Molvaer et al., 1997). Cr and Ni guideline values are not available. A. Concentraciones de metales ( $\mathrm{mg} / \mathrm{kg}$, peso seco) obtenidos en tejidos blandos de C. fluminea reportados en otros estudios similares. B. Clasificación de la calidad ecológica de ecosistemas acuáticos basados en la concentración de metales en tejidos blandos del mejillón azul Mytilus edulis (SFT TA-1467/1997) de acuerdo con la Norwegian Pollution Control Authority (Molvaer et al., 1997). Los valores umbrales para el Cr y Ni no están disponibles.

\begin{tabular}{|c|c|c|c|c|c|c|}
\hline Location & $\begin{array}{c}\text { Cd } \\
(\mathrm{mg} / \mathrm{kg})\end{array}$ & $\begin{array}{c}\mathrm{Cr} \\
(\mathrm{mg} / \mathrm{kg})\end{array}$ & $\begin{array}{c}\mathrm{Cu} \\
(\mathrm{mg} / \mathrm{kg})\end{array}$ & $\begin{array}{c}\mathrm{Ni} \\
(\mathrm{mg} / \mathrm{kg})\end{array}$ & $\begin{array}{c}\mathrm{Pb} \\
(\mathrm{mg} / \mathrm{kg})\end{array}$ & $\begin{array}{c}\mathrm{Zn} \\
(\mathrm{mg} / \mathrm{kg})\end{array}$ \\
\hline Minho estuary (our study) & $1.1-2.5$ & $1.0-1.8$ & $34-71$ & $5.8-11.0$ & $0.45-1.30$ & $136-161$ \\
\hline
\end{tabular}

A.

Range of metal concentrations observed in soft tissues of $C$. fluminea from several international wetlands

Shatt al-Arab River, Iraq [Abaychi \& Mustafa, 1998]

Rio de la Plata, Argentina [Bilos et al., 1998]

Cazaux-Sanguinet Lake, France [Marie et al., 2006]

Georgia Piedmont Basin, USA [Peltier et al., 2008]

New River, Virginia, USA [Rodgers et al., 1980]

2.2-70

$0.5-1.9$

- 40-1065

4.7

$31-83$

$0.15-4.2$

$1.3-11$

$28-89$

1.3-6.4

118-316

$0.8-4.1$

- $\quad 32.0-87.7$

- - -

20-29

Cazaux-Sanguinet Lake, France [Baudrimont et al., 2003]

5.9-6.9

$8.2-55$

$6.3-12$

$189.4-544.0$

$0.165-0.231$

- 5.5-7.7

B.

Ecological quality of the ecosystem (SFT TA-1467/1997) [Molvaer et al., 1997]

Class I-Unpolluted / Slightly Polluted

Class II-Moderately Polluted

Class III-Remarkably Polluted

Class IV-Highly Polluted

$\begin{array}{cccc}<2 & - & <10 & - \\ 2-5 & - & 10-30 & - \\ 5-20 & - & 30-100 & - \\ 20-40 & - & 100-200 & - \\ >40 & - & >200 & -\end{array}$

$\begin{array}{ccc}- & <3 & <200 \\ - & 3-15 & 200-400 \\ - & 15-40 & 400-1000 \\ - & 40-100 & 1000-2500 \\ - & >100 & >2500\end{array}$

$500-564$

23.5-28.5

Class V-Very Highly Polluted 
from water, efficiencies of assimilation from diets and efflux rate constants, involved in the bioaccumulation of each metal by $C$. fluminea.

\section{REFERENCES}

ABAYCHI, J. K., \& Y. Z. MUSTAFA. 1998. The Asiatic clam, Corbicula fluminea: an indicator of trace metal pollution in the Shatt al-Arab River, Iraq. Environmental Pollution, 54: 109-122.

ANTUNES, C. \& S. C. DIAS. 2005. The faunal composition of the euryhaline section of the Lima River estuary. Journal of Ichthyology, 45: 163-170.

APHA. 1998A. Standard Methods for the Examination of Water and Wastewater. Section: Metals; Method: 3010B-Introduction. 20th edition. American Public Health Association, Washington, DC.

APHA. 1998B. Standard Methods for the Examination of Water and Wastewater. Section: Metals; Method: 3111C-Flame Atomic AbsorptionExtracted Method. 20th edition. American Public Health Association, Washington, DC.

APHA. 1998C. Standard Methods for the Examination of Water and Wastewater. Section: Metals; Method: 3113B-Electrothermal Atomic Absorption. 20th edition. American Public Health Association, Washington, DC.

APHA. 1998D. Standard Methods for the Examination of Water and Wastewater. Section: Introdution; Method: 1030C-Data Quality. 20th edition. American Public Health Association, Washington, DC.

ARAUJO, R., D. MORENO \& M. A. RAMOS. 1993. The asiatic clam Corbicula fluminea (Müller, 1774) (Bivalvia: Corbiculidae) in Europe. American Malacological Bulletin, 10: 39-49.

ATTRILL, M. J. \& S. D. RUNDLE. 2002. Ecotone or ecocline: ecological boundaries in estuaries. Estuarine, Coastal and Shelf Science, 55: 929-936.

BAKKE, T., T. KALLQVIST, A. RUUS, G. D. BREEDVELD \& K. HYLLAND. 2010. Development of sediment quality criteria in Norway. Journal of Soils and Sediments, 10: 172-178.

BAUDRIMONT, M., S. ANDRES, G. DURRIEU, \& A. BOUDOU. 2003. The key role of metallothionein in the bivalve Corbicula fluminea during depuration phase, after in situ exposure to $\mathrm{Cd}$ and Zn. Aquatic Toxicology, 63: 89-102.
BAUDRIMONT, M., S. LEMAIRE-GONY, F. RIBEYRE, J. MÉTIVAUD, \& A. BOUDOU. 1997. Seasonal variations of metallothionein concentrations in the Asiatic clam (Corbicula fluminea). Comparative Biochemistry and Physiology - Part C, 118C: 361-367.

BILOS, C., J. C. COLOMBO, \& M. J. R. PRESA. 1998. Trace metals in suspended particles, sediments and Asiatic clams (Corbicula fluminea) of the Río de la Plata estuary, Argentina. Environmental Pollution, 99: 1-11.

CAÇADOR, I., C. VALE, \& F. CATARINO. 1996. Accumulation of $\mathrm{Zn}, \mathrm{Pb}, \mathrm{Cu}, \mathrm{Cr}$ and $\mathrm{Ni}$ in sediments between of the Tagus estuary salt marshes, Portugal. Estuarine, Coastal and Shelf Science, 42: 393-403.

CAEIRO, S., M. H. COSTA, T. B. RAMOS, F. FERNANDES, N. SILVEIRA, \& A. COIMBRA. 2005. Assessing heavy metal contamination in Sado estuary sediment: An index analysis approach. Ecological Indicators, 5: 151-169.

CAETANO, M., C. VALE, \& M. BEBIANNO. 2002. Distribution of $\mathrm{Fe}, \mathrm{Mn}, \mathrm{Cu}$ and $\mathrm{Cd}$ in upper sediments and sediment-trap material of Ria Formosa (Portugal). Journal of Coastal Research, 36: 118123.

CLARKE, K. R. \& R. M. WARWICK. 2001. Change in Marine Communities: an approach to statistical analysis and interpretation. $2^{\text {nd }}$ edition, PRIMERE Ltd, Plymouth Marine Laboratory, Plymouth.

COSTA-DIAS, S., R. SOUSA, \& C. ANTUNES. 2010. Ecological quality assessment of the lower Lima estuary. Marine Pollution Bulletin, 61: 234-239.

FRANÇA, S., C. VINAGRE, I. CAÇADOR, \& H. N. CABRAL. 2005. Heavy metal concentration in sediment, benthic invertebrates and fish in three salt marsh areas subjected to different pollution loads in the Tagus Estuary (Portugal). Marine Pollution Bulletin, 50: 993-1018.

INZA, B., E. RIBEYRE, R. MAURY-BRACHET, \& A. BOUDOU. 1997. Tissue distribution of inorganic mercury, methilmercury and cadmium in the Asiatic clam (Corbicula fluminea) in relation to the contamination levels of the water column and sediment. Chemosphere, 35: 2817-2836.

MARIE, V., M. BAUDRIMONT, \& A. BOUDOU. 2006. Cadmium and zinc bioaccumulation and metallothionein response in two freshwater bivalves (Corbicula fluminea and Dreissena poly- 
morpha) transplanted along a polymetallic gradient. Chemosphere, 65: 609-617.

MAZE, R. A., M. LASTRA, \& J. MORA. 1993. Macrozoobentos del estuário del Miño (NO de España). Publicaciones Especiales Instituto Español de Oceanografia, 11: 283-289.

MOLVÆR, J., J. KNUTZEN, J. MAGNUSSON, B. RYGG, J. SKEI, \& J. SØRENSEN. 1997. Classification of environmental quality in fjords and coastal waters. A guide. Norwegian Pollution Control Authority SFT TA-1467/1997.

MONTERROSO, P., P. PATO, E. PEREIRA, C. VALE, \& A. C. DUARTE. 2003. Distribution and accumulation of metals $(\mathrm{Cu}, \mathrm{Cd}, \mathrm{Zn}$ and $\mathrm{Pb})$ in sediments of a lagoon on the northwestern coast of Portugal. Marine Pollution Bulletin, 46: 1200-1211.

MORENO, F., M. F. ARAÚJO, J. MORENO, F. FATELA, \& T. DRAGO. 2005. Caracterização geoquímica de sedimentos superficiais do estuário do Minho e do sapal de Caminha (NW de Portugal)-estimativa do potencial de stress biológico, Proceedings of the XIV Week of Geochemistry/VIII Congress of Geochemistry of Countries of Portuguese Language, University of Aveiro, Portugal.

MUCHA, A. P., M. T. S. D. VASCONCELOS, \& A. A. BORDALO. 2003. Macrobenthic community in the Douro estuary: Relations with trace metals and natural sediments characteristics. Environmental Pollution, 121: 169-180.

MUCHA, A. P., M. T. S. D. VASCONCELOS, \& A. A. BORDALO. 2004. Vertical distribution of the macrobenthic community and its relationship to trace metals and natural sediment characteristics in the lower Douro estuary, Portugal. Estuarine, Coastal and Shelf Science, 59: 663-673.

PADINHA, C., R. SANTOS, \& M. T. BROWN. 2000. Evaluating environmental contamination in Ria Formosa (Portugal) using stress indexes of Spartina marítima, Marine Environmental Research, 49: 67-78.

PAIVA, P. C., M. C. ARAUJO, J. M. DIAS, \& J. M. JOUANNEAU. 1993. Distribuição Elementar em Sedimentos do Rio Minho, Proceedings of the II Congress of Geochemistry of Countries of Portuguese Language, Department of Mineralogy and Geology, Faculty of Sciences, University of Oporto, Portugal.

PELTIER, G. L., J. L. MEYER, C. H. JAGOE, \& W. A. HOPKINS. 2008. Using trace element concen- trations in Corbicula fluminea to identify potential sources of contamination in an urban river. Environmental Pollution, 154: 283-290.

PHELPS, H. L. 1994. The Asiatic clam (Corbicula fluminea) invasion and system-level ecological change in the Potomac River Estuary near Washington, D.C. Estuaries, 17: 614-621.

REIS, P. A. \& C. M. R. ALMEIDA. 2008. Matrix importance in animal material pre-treatment for metal determination. Food Chemistry, 107: 12941299.

REIS, P. A., J. C. ANTUNES, \& C. M. R. ALMEIDA. 2009. Metal levels in sediments from the Minho estuary salt marsh: a metal clean area? Environmental Monitoring and Assessment, 159: 191-205.

REIS, P. A., M. A. SALGADO, \& V. VASCONCELOS. 2012A. Chthamalus montagui as biomonitor of metal contamination in the northwest coast of Portugal. Environmental Monitoring Assessment, 184: 5421-5437.

REIS, P. A., M. A. SALGADO, \& V. VASCONCELOS. 2012B. Goose barnacle Pollicipes pollicipes as biomonitor of metal contamination in the northwest coast of Portugal. Environmental Monitoring Assessment, 184: 6987-7000.

RODGERS, J. H., D. S. CHERRY, R. L. GRANEY, K. L. DIKSON, \& J. CAIRNS. 1980. Comparison of heavy metal interactions in acute and artificial stream bioassay techniques for the Asiatic clam (Corbicula fluminea). In: Eaton JG, Parrrish PR, Hendricks AC Eds., Aquatic Toxicology, ASTM STP 707. American Society of Testing and Materials, Philadelphia, PA.

RUNDLE, S. D., M. J. ATTRILL, \& A. ARSHAD. 1998. Seasonality in macroinvertebrates community composition across a neglected ecological boundary, the freshwater-estuarine transition zone. Aquatic Ecology, 32: 211-216.

SOUSA, R., C. ANTUNES, \& L. GUILHERMINO. 2006. Factors influencing the occurrence and distribution of Corbicula fluminea (Müller, 1774) in the River Lima estuary. Annales de LimnologieInternational Journal of Limnology, 42: 165-171.

SOUSA, R., C. ANTUNES, \& L. GUILHERMINO. 2007. Species composition and monthly variation of the Molluscan fauna in the freshwater subtidal area of the River Minho estuary. Estuarine, Coastal and Shelf Science, 75: 90-100.

SOUSA, R., C. ANTUNES, \& L. GUILHERMINO. 2008B. Ecology of the invasive Asian clam Corbicula fluminea (Müller, 1774) in aquatic ecosys- 
tems: an overview. Annales de Limnologie-International Journal of Limnology, 44: 85-94.

SOUSA, R, S. DIAS, L. GUILHERMINO, \& C. ANTUNES. 2008A. Minho River tidal freshwater wetlands: threats to faunal biodiversity. Aquatic Biology, 3: 237-250.

SOUSA, R., L. GUILHERMINO, \& C. ANTUNES. 2005. Molluscan fauna in the freshwater tidal area of the River Minho estuary, NW of Iberian Peninsula. Annales de Limnologie-International Journal of Limnology, 41: 141-147.

SOUSA, R., M. RUFINO, M. GASPAR, C. ANTUNES, \& L. GUILHERMINO. 2008C. Abiotic impacts on spatial and temporal distribution of Corbicula fluminea (Müller, 1774) in the River Minho estuary, Portugal. Aquatic Conservation: Marine Freshwater Ecosystems, 18: 98-110.
US-EPA ENVIRONMENTAL PROTECTION AGENCY. 1994. Method 3051: Microwave assisted acid digestion of sediments, sludges and soils. US EPA Office of Solid Waste, Washington DC.

VARIAN. 1988. Analytical Methods for graphite Tube Atomizers. Publication No. 85-100848-00. Varian Australia Pty Ltd., Mulgrave, Australia.

VARIAN. 1989. Analytical Methods for Flame Atomic Absorption Spectrometry. Publication No. 85100009-00. Varian Australia Pty Ltd., Mulgrave, Australia.

YSEBAERT, T., P. M. J. HERMAN, P. MEIRE, J. CRAEYMEERSCH, H. VERBEEK, \& C. H. R. HEIP. 2003. Large-scale spatial patterns in estuaries: estuarine macrobenthic communities in the Schelde estuary, NW Europe. Estuarine, Coastal and Shelf Science, 57: 335-355. 